A Politics of the Scene 



\title{
A Politics of the Scene
}

\author{
Paul A. Kottman
}

$\approx$

STANFORD UNIVERSITY PRESS

STANFORD, CALIFORNIA

2008 
Assistance for this publication was provided by

The New School for Social Research

Stanford University Press,

Stanford California

(C) 2008 by the Board of Trustees of the

Leland Stanford Junior University

All rights reserved

No part of this book may be reproduced or transmitted in any form or by any means, electronic or mechanical, including photocopying and recording, or in any information storage or retrieval system without the prior written permission of Stanford University Press.

Library of Congress Cataloging-in-Publication Data

Kottman, Paul A.

A politics of the scene / Paul A. Kottman.

p. $\mathrm{cm}$.

Includes bibliographical references and index.

ISBN 978-0-8047-5834-5 (cloth : alk. paper)

I. Shakespeare, William, $\mathrm{x}_{564-16 \mathrm{r} 6-C r i t i c i s m}$ and interpretation.

2. Shakespeare, William, I564-1616-Political and social views.

3. Plato-Political and social views. 4. Hobbes, Thomas, I $588-$ r679-Political and social views. 5. Political science-Philosophy.

6. Philosophy in literature. I. Title.

PR300I.K68 2008

$822.3^{\prime} 3-\mathrm{dc} 22$

2007018008

Printed in the United States of America on acid-free, archival-quality paper

Typeset at Stanford University Press in Io/ I2.5 Sabon 
For my parents,

Karl and Mary Kottman 
